\title{
POLSKA WYTWÓRNIA PAPIERÓW WARTOŚCIOWYCH SA W SYSTEMIE BEZPIECZEŃSTWA EKONOMICZNEGO I PUBLICZNEGO
}

Słowa kluczowe: PWPW, bezpieczeństwo ekonomiczne, podstawowy interes bezpieczeństwa państwa.

Klasyfikacja J E L: D22, G38, H56, H82, K23.

\begin{abstract}
Abstrakt: Artykuł dotyczy usytuowania PWPW w systemie bezpieczeństwa ekonomicznego i publicznego. Zzdefiniowano i omówiono w nim dwie szczególne kategorie bezpieczeństwa, związane z działalnością PWPW, tj. bezpieczeństwo identyfikacyjne oraz bezpieczeństwo transakcyjne. Przedstawiono najważniejsze czynniki kształtujące powyższe kategorie bezpieczeństwa oraz relacje pomiędzy bezpieczeństwem identyfikacyjnym i transakcyjnym a bezpieczeństwem ekonomicznym i publicznym. Artykuł prowadzi do konkluzji, że PWPW pełni istotną funkcję w systemie bezpieczeństwa ekonomicznego państwa, a działalność gospodarcza prowadzona przez PWPW w zakresie produkcji banknotów i dokumentów wraz z towarzyszącymi im systemami IT tworzy podstawowy interes bezpieczeństwa państwa.
\end{abstract}

\section{Polish Security Printing Works IN THE SYSTEM OF PUBLIC AND ECONOMIC SECURITY}

Keywords: PWPW, economic security, fundamental interest od state's security. J E L Classification: D22, G38, H56, H82, K23.

Abstract: The article raises the issue of placing PWPW in the system of economic and public security. Two particular categories of security connected with PWPW business activity, i.e. identification and transactional security, have been defined and discussed in the article. The most essential factors affecting the above security categories as well

Data wpłynięcia: 05.06.2013; data zaakceptowania: 29.10.2013.

* Dane kontaktowe: r.lewandowski@pwpw.pl, ul. Sanguszki 1, 00-222 Warszawa, tel. 225302158. 
as relations between identification/transactional security and economic/public security. The article indicates that PWPW plays an important role in the state's economic security system and the business activity of PWPW, including banknote, document and related software's production, creates the fundamental interest of state's security.

Translated by Remigiusz Lewandowski

\section{UII WSTĘP}

Realizacja misji bezpieczeństwa państwa jest zagadnieniem dotyczącym nie tylko organów państwa i sił zbrojnych, ale również dotykającym podmioty tworzące państwo, w szczególności społeczeństwo oraz podmioty gospodarcze. W gospodarce niektóre przedsiębiorstwa mają krytyczne znaczenie dla bezpieczeństwa państwa. Zakłócenie ich funkcjonowania, w warunkach zarówno pokoju, jak i wojny, może doprowadzić do osłabienia bezpieczeństwa państwa. Stąd przepisy prawa nakładają na niektóre przedsiębiorstwa, których działalność jest kluczowa z punktu widzenia bezpieczeństwa państwa, szereg zadań i szczególnych wymagań. Niniejszy artykuł skupia się na funkcji Polskiej Wytwórni Papierów Wartościowych SA (dalej: PWPW) - podmiotu zapewniającego wiarygodność procesów transakcji i identyfikacji - w systemie bezpieczeństwa ekonomicznego i publicznego.

\section{MeTODYKA}

Artykuł oparto na studium przypadku PWPW przy wykorzystaniu analizy aktualnego stanu prawnego, a także literatury przedmiotu dotyczącej bezpieczeństwa narodowego oraz bezpieczeństwa publicznego i ekonomicznego.

\section{PRZEGLĄD WYBRANYCH REGULACJI PRAWNYCH}

Ustawa z dnia 26 kwietnia 2007 r. o zarzq̨dzaniu kryzysowym m.in. w art. 6 ust. 5 nakłada na właścicieli oraz posiadaczy samoistnych i zależnych obiektów, instalacji lub urządzeń infrastruktury krytycznej obowiązek ich ochrony oraz utrzymywanie własnych systemów rezerwowych, zapewniających bezpieczeństwo i podtrzymujących funkcjonowanie tej infrastruktury. Przez infrastrukturę krytyczna, zgodnie z art. 3 pkt 2 ww. ustawy, należy rozumieć systemy oraz wchodzące $w$ ich skład powiązane ze sobą funkcjonalnie obiekty, urządzenia, instalacje, usługi kluczowe dla bezpieczeństwa państwa i jego 
obywateli oraz służące zapewnieniu sprawnego funkcjonowania organów administracji publicznej, a także instytucji i przedsiębiorców. Infrastruktura krytyczna obejmuje m.in. systemy finansowe i zapewniające ciągłość działania administracji publicznej, które bezpośrednio wiążą się z działalnością PWPW w zakresie produkcji banknotów oraz dokumentów komunikacyjnych i identyfikacyjnych oraz towarzyszących im systemów teleinformatycznych. Nota bene kluczowy z punktu widzenia państwa przedmiot działalności PWPW można, opierając się na misji spółki, zdefiniować bardziej kompleksowo jako produkty i usługi zapewniające wiarygodność procesów transakcji i identyfikacji. Wykaz infrastruktury krytycznej tworzony jest w ramach planów zarządzania kryzysowego na poziomie krajowym, wojewódzkim, powiatowym i gminnym. Przedsiębiorcy - operatorzy infrastruktury krytycznej, na podstawie rozporządzenia Rady Ministrów z dnia 30 kwietnia 2010 r. w sprawie planów ochrony infrastruktury krytycznej, sporządzają odpowiednie plany ochrony. Obowiązek taki dotyczy również PWPW.

Ponadto ustawa z dnia 23 sierpnia 2001 r. o organizowaniu zadań na rzecz obronności państwa realizowanych przez przedsiębiorców określa zasady organizowania zadań na rzecz obronności państwa przez przedsiębiorców, w tym przez przedsiębiorców o szczególnym znaczeniu gospodarczo-obronnym. Zadania te dotyczą m.in. mobilizacji gospodarki, militaryzacji i planowania operacyjnego. Są one nakładane na przedsiębiorców w drodze decyzji administracyjnej, a ich wykonanie następuje na podstawie umów zawartych z organem wydającym decyzję. Na mocy rozporządzenia Rady Ministrów z dnia 4 października 2010 r. w sprawie wykazu przedsiębiorców o szczególnym znaczeniu gospodarczo-obronnym PWPW jest zaliczana do tego rodzaju podmiotów.

Do działalności prowadzonej przez PWPW odnosi się również rozporządzenie Rady Ministrów z dnia 22 października 2010 r. w sprawie określenia przedsiębiorstw państwowych oraz jednoosobowych spótek Skarbu Państwa o szczególnym znaczeniu dla gospodarki państwa.

Szczególny charakter podmiotów gospodarczych pełniących kluczowe funkcje w systemie bezpieczeństwa państwa widoczny jest także w ustawie z dnia 29 stycznia 2004 r. Prawo zamówień publicznych. W 2012 r. w ustawie tej dokonano zmian, które dotykają przedmiotowego zagadnienia. Między innymi w art. 4 pkt 5) w większym stopniu sprecyzowano warunki, w których nie stosuje się ustawy. Za zrozumiałe należy uznać, że ze względów bezpieczeństwa niektóre zamówienia państwowe nie są poddane zasadom wolnego rynku i wolnej konkurencji. Ze stosowania ustawy wyłączono zatem zamówienia, 
którym nadano klauzulę „tajne” lub „ściśle tajne”, zgodnie z przepisami o ochronie informacji niejawnych, lub jeżeli wymaga tego istotny interes bezpieczeństwa państwa lub ochrona bezpieczeństwa publicznego. We wcześniej obowiązującym brzmieniu wyłączenie to dotyczyło zamówień zawierających informacje niejawne, jeżeli wymaga tego istotny interes publiczny lub istotny interes państwa. W konsekwencji zawężono interes państwa (lub interes publiczny) wyłącznie do istotnego interesu bezpieczeństwa państwa lub ochrony bezpieczeństwa publicznego. Ustawodawca tym samym zwrócił uwagę na znaczenie kwestii bezpieczeństwa jako kluczowej dla wyłączeń z ustawy Prawo zamówień publicznych. Ponadto zawężono katalog zamówień wyłączanych z ustawy ze względu na ochronę informacji - z szerokiego katalogu informacji niejawnych na zamówienia, którym nadano klauzulę „tajne” lub „ściśle tajne”. Równocześnie jednak należy zauważyć, że pierwotna formuła wyłączenia miała charakter warunkowy, tj. opierała się co do zasady na zawartych w zamówieniu informacjach niejawnych, jeżeli wymagał tego istotny interes publiczny lub istotny interes państwa. W obecnie obowiązującym brzmieniu wyłączenia ustawodawca zapewnił alternatywę różnych czynników, tj. odpowiedniej klauzuli tajności lub wymóg istotnego interesu bezpieczeństwa państwa albo ochrony bezpieczeństwa publicznego. A zatem, zgodnie z art. 4 pkt 5) ustawy Prawo zamówień publicznych wystarczające jest spełnienie tylko jednego z trzech warunków, aby nie stosować przepisów ustawy.

Ponadto, zgodnie z art. 4b ust 1 pkt 2) w związku z art. 131a ust. 1 omawianej ustawy, wyłączenie obejmuje także m.in. zamówienia na newralgiczne usługi, w przypadku których stosowanie przepisów ustawy zobowiq̨zywałoby zamawiajqcego do przekazania informacji, których ujawnienie jest sprzeczne z podstawowymi interesami bezpieczeństwa państwa. Termin usługi newralgiczne ustawodawca zdefiniował w art. 2 pkt 5c) jako usługi do celów bezpieczeństwa, które wiq̨żq się z korzystaniem z informacji niejawnych, wymagaja ich wykorzystania lub je zawierają. Prawo zamówień publicznych nie definiuje podstawowego interesu bezpieczeństwa państwa. Zgodnie z art. 4c tryb postępowania w sprawie oceny występowania podstawowego interesu państwa regulowany jest rozporządzeniem Rady Ministrów. Rozporządzenie z dnia 12 lutego 2013 r. przewiduje, że oceny występowania podstawowego interesu bezpieczeństwa państwa dokonuje minister kierujący działem administracji rządowej, któremu podlega zamawiająca jednostka organizacyjna, na wniosek dyrektora odpowiedniej komórki organizacyjnej ministerstwa. Wniosek o dokonanie oceny powinien zawierać m.in. uzasadnienie, które wskazuje podstawowy interes bezpieczeństwa pań- 
stwa oraz przesłankę przyczynowo-skutkową wiążącą przedmiot zamówienia z podstawowym interesem bezpieczeństwa państwa, $\mathrm{w}$ tym opis wpływu udzielenia zamówienia na podstawowy interes bezpieczeństwa państwa. Wyłączenia ze stosowania ustawy Prawo zamówień publicznych wynikać także mogą z innych przyczyn, takich jak funkcjonowanie w ramach państwa monopolu naturalnego ${ }^{1}$, uzasadnionego (z natury rzeczy) względami ekonomicznymi (korzyści skali, korzyści zakresu, spełniony warunek subaddy tywności, unikatowe kompetencje, niepodzielność specyficznych czynników produkcji etc.).

Istnieje ponadto szereg innych regulacji prawnych zabezpieczających wykonywanie zadań produkcyjnych lub usługowych przez podmioty gospodarcze, których działalność jest ważna dla bezpieczeństwa państwa. Dotyczą one w szczególności przepisów regulujących dany sektor gospodarki i zapewniających ciągłość świadczenia usług (np. ustawa z dnia 16 lipca 2004 r. Prawo telekomunikacyjne, ustawa z dnia 16 lutego 2007 r. o zapasach ropy naftowej, produktów naftowych i gazu ziemnego oraz zasadach postępowania w sytuacjach zagrożenia bezpieczeństwa paliwowego państwa i zakłóceń na rynku naftowym). Niemniej jednak przedmiot działalności gospodarczej podmiotów, do których odnoszą się tego rodzaju regulacje, nie obejmuje bezpośrednio sfer bezpieczeństwa państwa, takich jak np. produkcja dokumentów i związanych z nimi systemów IT czy produkcja środków pieniężnych, a w szczególności banknotów.

\section{BEZPIECZEŃSTWO I JEGO DZIEDZINY}

Biorąc pod uwagę powyższe uregulowania, szczególnie ważne pozostaje poprawne rozumienie bezpieczeństwa państwa oraz podstawowego interesu bezpieczeństwa państwa. Jest to szczególnie trudne z uwagi na brak definicji obu terminów w przepisach prawa. Co więcej, w literaturze przedmiotu, która nota bene nie jest szczególnie rozwinięta, panuje spora dowolność terminologiczna odnosząca się do bezpieczeństwa narodowego, bezpieczeństwa publicznego, bezpieczeństwa państwa czy bezpieczeństwa wewnętrznego, a termin podstawowy interes bezpieczeństwa państwa czeka na swoją naukową interpretację.

Niniejszy artykuł, przynajmniej w jakimś stopniu, pojęcie to wypełnia treścią. Na jego potrzeby proponuje się przyjąć systematykę, zgodnie z którą naj-

1 Przykładem monopoli naturalnych funkcjonujących w Polsce jest PSE Operator SA (linie przesyłowe energii elektrycznej) czy Gaz-System SA (linie przesyłowe gazu); pewnymi cechami monopolu naturalnego odznacza się również PWPW SA; szerzej w: Lewandowski 2013, 9-20. 
szerszą kategorią bezpieczeństwa jest bezpieczeństwo narodowe, rozumiane jako „najważniejsza wartość, potrzeba narodowa i priorytetowy cel działalności państwa, jednostek i grup społecznych, a jednocześnie proces obejmujący różnorodne środki, gwarantujące trwały, wolny od zakłóceń byt i rozwój narodowy (państwa), w tym ochronę i obronę państwa jako instytucji politycznej oraz ochronę jednostek i całego społeczeństwa, ich dóbr i środowiska naturalnego przed zagrożeniami, które w znaczący sposób ograniczają jego funkcjonowanie lub godzą w dobra podlegające szczególnej ochronie" (Kitler 2011, 31). Przytoczona definicja jest bardzo pojemna. Obejmuje bowiem zarówno kwestie bezpieczeństwa zewnętrznego, jak i wewnętrznego, a ponadto odnosi się także do wartości ważnych dla społeczeństwa. Definicja ta może jednak budzić wątpliwości w przypadku wąskiego rozumienia terminu narodowy, ograniczającego się do narodu, a zatem do wspólnoty o podłożu etnicznym. We współczesnych państwach demokratycznych, złożonych ze społeczeństw często wielonarodowych, tego rodzaju zawężenie jest niedopuszczalne. W niniejszym artykule zatem bezpieczeństwo narodowe odnosi się nie do określonego narodu, ale do całego społeczeństwa. Wydaje się więc, że ta kwestia terminologiczna wymaga dalszych prac badawczych i prawdopodobnie nowych propozycji w tym zakresie.

Kategorią węższą od bezpieczeństwa narodowego jest bezpieczeństwo państwa definiowane jako „bezpieczeństwo instytucji politycznej, posiadającej suwerenną władzę, określone terytorium, a także ludność podległą ciału władczemu” i zorientowane na „utrzymanie porządku w zbiorowości państwowej oraz zapewnienie jej bezpieczeństwa zewnętrznego i wewnętrznego" (Kitler 2011, 27). Kategoria ta jest zatem węższa od kategorii bezpieczeństwa narodowego o kwestie związane z wartościami istotnymi dla społeczeństwa, które podlegają ochronie.

Sulowski $(2009,12-13)$ z kolei precyzuje termin bezpieczeństwa wewnętrznego, odnosząc je do „stałej gotowości i działalności określonych instytucji oraz organów państwowych, a także prywatnych podmiotów, która ma znaczenie dla zachowania stabilności i integralności państwa”. Tym samym Sulowski przyjmuje, że bezpieczeństwo wewnętrzne ma wymiar szerszy aniżeli bezpieczeństwo publiczne, albowiem obejmuje także sferę prywatną wewnątrz państwa. Zbliżoną definicję proponuje również Majer $(2012,16)$, podkreślając znaczenie triady bezpieczeństwa organów państwa, bezpieczeństwa osobistego i bezpieczeństwa egzystencji w bezpieczeństwie wewnętrznym. Misiuk zaś (2008, 16-17) przedstawia definicję bezpieczeństwa publicznego jako „stan 
braku zagrożenia dla funkcjonowania organizacji państwowej i realizacji jej interesów, umożliwiający normalny, swobodny jej rozwój", przy czym zwykle pojęcie to odnosi się wyłącznie do państwa i działań podejmowanych przez państwo i dotyczy sfery wewnętrznej państwa.

Na schemacie 1 przedstawiono proponowaną strukturę bezpieczeństwa narodowego.

Schemat 1. Dziedziny bezpieczeństwa konstytuujące bezpieczeństwo narodowe

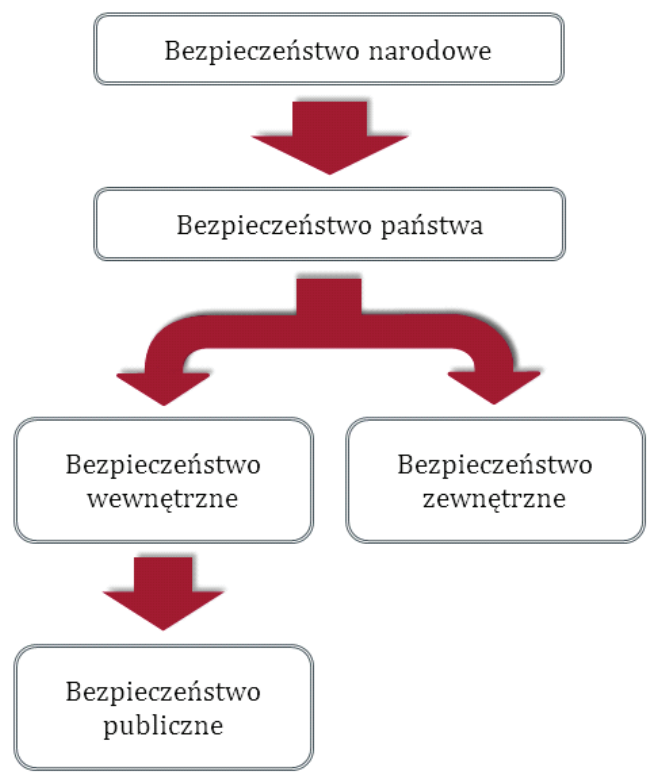

Źr ó d ło : opracowanie własne.

\section{PODSTAWOWY INTERES BEZPIECZEŃSTWA PAŃSTWA}

Problematyczna pozostaje kwestia terminu podstawowego interesu bezpieczeństwa państwa. Przymiotnik podstawowy sugeruje, że chodzi o wąskie rozumienie interesu bezpieczeństwa, o de facto jego rdzeń, innymi słowy kluczowy interes państwa. Ustawodawca nie wskazał kryteriów, jakie interes bezpieczeństwa państwa mu spełniać, aby być uznanym za podstawowy. Zgodnie z przytaczanym rozporządzeniem Rady Ministrów z dnia 12 lutego 2013 r. oceny takiej w przypadku zamówień rządowych związanych ze sferą bezpieczeństwa państwa dokonuje odpowiedni minister. Istotne pozostaje także po- 
prawne rozumienie terminu interes bezpieczeństwa państwa. Popiuk-Rysińska $(2000,99)$ przyjmuje, że interes można określić jako „pożądane stany rzeczy, które są osiągane lub chronione przez podmioty, lub - innymi słowy - takie dobra, których brak lub niedobór, aktualny bądź antycypowany, wywołuje działanie podmiotu". Z kolei Kukułka $(2000,244)$ bezpośrednio wiąże interes państwa z potrzebami i celami narodowymi, twierdząc, że „w toku realizacji potrzeby aspiracyjne przekształcają się w potrzeby operacyjne, które przejawiają się jako interesy. Są one formą wyrażania i ukierunkowania realizowanych potrzeb, a zarazem tworzą ogniwo łączące owe potrzeby z celami narodów, państw [...]”. Na tym tle pojęcie podstawowego interesu bezpieczeństwa państwa należy zatem rozumieć jako kluczowe potrzeby państwa zapewniające jego bezpieczeństwo. Te kluczowe potrzeby państwa dotyczą:

- bezpieczeństwa militarnego,

- bezpieczeństwa politycznego,

- bezpieczeństwa publicznego,

- bezpieczeństwa ekonomicznego.

Podkreślenia wymaga fakt, że w ramach każdej z wyżej wymienionych kategorii można odnaleźć zarówno zjawiska faktycznie istotne dla bezpieczeństwa państwa i stanowiące o podstawowym interesie bezpieczeństwa państwa, jak i zjawiska, które z punktu widzenia bezpieczeństwa państwa i podstawowego interesu bezpieczeństwa państwa mają charakter marginalny. Dotyczyć to może na przykład sytuacji ekonomicznej poszczególnych przedsiębiorstw. Co do zasady, sytuacja pojedynczych podmiotów gospodarczych oraz ich działalność nie ma realnego wpływu na bezpieczeństwo państwa. Natomiast w przypadku przedsiębiorstw pełniących szczególne funkcje w gospodarce (np. podmioty uznane za kluczowe dla polskiej gospodarki, jak PWPW) tego rodzaju wpływ istnieje. Jak wskazuje Kitler $(2011,42)$, dotyczy to w szczególności sytuacji, gdy działalność danej spółki ma wpływ na rozwój państwa oraz gdy danej spółce powierzone są zadania na rzecz realizacji celów bezpieczeństwa narodowego, tak jak w przypadku PWPW wytwarzającej na zlecenia państwa banknoty, dokumenty i odpowiednie systemy IT.

\section{DZIAŁALNOŚć PWPW A BEZPIECZEŃSTWO PAŃSTWA I PODSTAWOWY INTERES BEZPIECZEŃSTWA PAŃSTWA}

Niniejszy artykuł obejmuje analizę czynników związanych z działalnością gospodarczą PWPW i wskazuje na silną relację pomiędzy przedmiotem działal- 
ności gospodarczej PWPW a podstawowym interesem bezpieczeństwa państwa. W relacji tej w szczególności uczestniczy bezpieczeństwo ekonomiczne oraz bezpieczeństwo publiczne.

Bezpieczeństwo ekonomiczne obejmuje całokształt środków w dziedzinie bezpieczeństwa narodowego, których zasadniczym celem jest zapewnienie takiego stanu rozwoju systemu gospodarczego państwa, jaki „zapewnia wysoką sprawność jego funkcjonowania oraz zdolność do skutecznego przeciwstawienia się zewnętrznym naciskom, mogących doprowadzić do zaburzeń rozwojowych" (Płaczek 2006, 113). Szczególną rolę w tej dziedzinie bezpieczeństwa odgrywa stabilność systemu płatniczego, związana z pewnością i wiarygodnością realizowanych transakcji. W tym aspekcie, z punktu widzenia bezpieczeństwa zapewnianego przez PWPW, kluczową funkcję pełni pewność w zakresie emitowanego pieniądza ${ }^{2}$ (np. zabezpieczenie przed fałszerstwami, nieuprawnionym wprowadzaniem do obrotu etc.) oraz w zakresie procesów identyfikacyjnych (np. zabezpieczenie przed tworzeniem fałszywych tożsamości na potrzeby działalności przestępczej, nieuprawnionym dostępem do systemów teleinformatycznych i kradzieżą danych). Stąd zasadnicze znaczenie mają tu zagrożenia związane z przestępczością gospodarczą czy praniem brudnych pieniędzy, a także wspomniane zagrożenia dla stabilności systemu płatniczego, które swoje źródła czerpać mogą z naruszeń bezpieczeństwa identyfikacyjnego i transakcyjnego. Mogą to być zagrożenia, które generują istotne szkody dla systemu gospodarczego państwa lub mogą powodować jego zachwianie, co uznawane jest za działania godzące w podstawowe interesy ekonomiczne państwa (Grzemski 2010, 150). W literaturze przedmiotu wśród zagrożeń dla bezpieczeństwa ekonomicznego wskazuje się również utratę kontroli przez państwo nad branżami strategicznymi oraz reglamentację i utrudniony dostęp do nowych technologii (Kitler 2011, 50). Zakres wpływu zapewnianej przez PWPW wiarygodności procesów transakcji i identyfikacji - $\mathrm{w}$ ramach podstawowego interesu bezpieczeństwa państwa - przedstawiono na schemacie 2.

${ }^{2}$ Choć obecnie PWPW SA wytwarza na potrzeby Narodowego Banku Polskiego banknoty złotówkowe, to równocześnie przygotowuje się do produkcji banknotów euro na potrzeby Polski w momencie przystąpienia RP do Europejskiej Unii Monetarnej. 
Schemat 2. Sfera wpływu bezpieczeństwa identyfikacyjnego i transakcyjnego w ramach podstawowego interesu bezpieczeństwa państwa

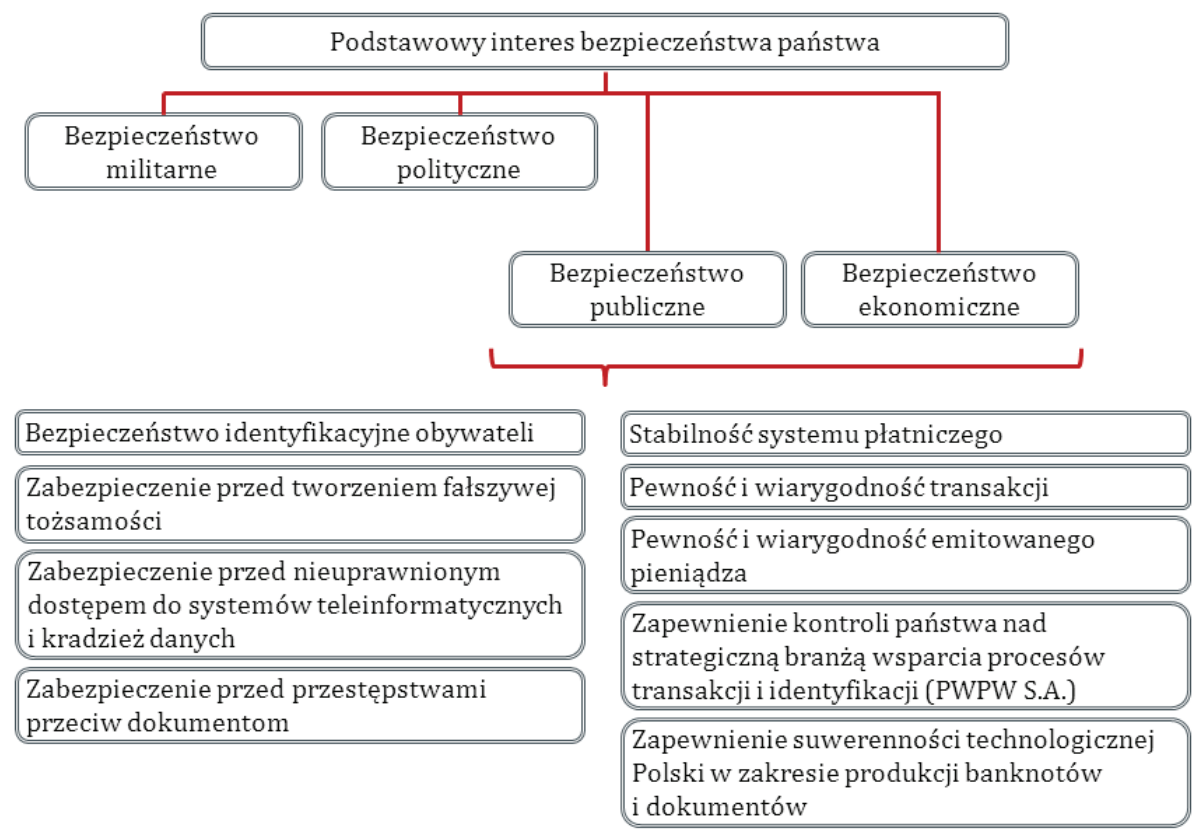

Źr ó d ło : opracowanie własne.

Waga, z jaką państwo traktuje zagadnienia bezpieczeństwo obrotu pieniędzmi oraz wiarygodności dokumentów, znajduje swoje odzwierciedlenie np. w surowych sankcjach przewidzianych w kodeksie karnym. Zgodnie z art. 310 $\S 1$ k.k., „kto podrabia albo przerabia polski albo obcy pieniądz [...] podlega karze pozbawienia wolności na czas nie krótszy od 5 lat albo karze 25 lat pozbawienia wolności”. Ponadto, w myśl art. $270 § 1$ k.k., „kto, w celu użycia za autentyczny, podrabia lub przerabia dokument lub takiego dokumentu jako autentycznego używa, podlega grzywnie, karze ograniczenia wolności albo pozbawienia wolności od 3 miesięcy do lat 5".

Z kolei, jak wskazują Brzęk i Goc $(2006,3)$, „dobre zabezpieczenie przed fałszerstwem wybranych kategorii dokumentów ma istotne znaczenie dla bezpieczeństwa państwa, jego ekonomicznych interesów, dla bezpieczeństwa obrotu ekonomicznego i prawnego oraz dla bezpieczeństwa samych obywateli". Utrata zaś wiarygodności dokumentów bezpośrednio narusza bezpieczeństwo państwa (Maciejewski 2007, 9). Związek przyczynowo-skutkowy pomiędzy wiary- 
godnością dokumentów i środków pieniężnych a bezpieczeństwem państwa i podstawowym interesem bezpieczeństwa państwa jest zatem bezsporny.

Bezpieczeństwo publiczne z kolei wiąże się z „zapewnieniem niezakłóconego funkcjonowania instytucji państwa i jego obywateli" (Kitler 2011, 56) i - w węższym ujęciu - dotyczy „kwestii ochrony porządku prawnego, publicznego, ładu wewnętrznego, a także przed wszelkimi działaniami zabronionymi" (Kitler 2011, 58). W tym ujęciu, z punktu widzenia bezpieczeństwa zapewnianego przez PWPW dotyczy zatem również zapewniania prawidłowości obrotu gospodarczego, wiarygodności dokumentów oraz ochrony informacji i danych osobowych - poprzez zapewnienie wiarygodności identyfikacji stron transakcji i wiarygodności środków pieniężnych oraz procesów z nimi związanych. Wiarygodność ta tworzona jest przez następujące elementy: bezpośredni nadzór państwa nad PWPW, kluczowe kompetencje i know-how posiadane przez spółkę oraz efektywność prowadzonej działalności gospodarczej. Elementem dopełniającym ten kwartet wartości konstytuujących wiarygodność procesów transakcji i identyfikacji zapewnianej przez PWPW powinny być odpowiednie regulacje prawne oraz polityka państwa w zakresie bezpieczeństwa identyfikacyjnego i transakcyjnego. Osobnym produktem tych wartości jest ponadto wartość dla akcjonariusza (Skarbu Państwa) płynąca z działalności realizowanej przez PWPW w postaci podatków, dywidendy, wpłaty z zysku i innych transferów pieniężnych do państwa oraz w postaci wartości samego przedsiębiorstwa. Wartość ta wynika nie tylko z działalności PWPW na krajowym rynku banknotów i dokumentów, ale również z działalności na krajowych komercyjnych rynkach produktów i usług IT oraz na rynkach zagranicznych banknotów, dokumentów i związanych z nimi systemów IT. Na schemacie 3 przedstawiono relacje pomiędzy wskazanymi wartościami a wiarygodnością procesów transakcji i identyfikacji oraz korzyściami dla akcjonariusza.

Podkreślenia wymaga fakt, że nie ma zapisów normatywnych regulujących pozycję PWPW w zakresie jej obecności na krajowym rynku banknotów i dokumentów. Z drugiej strony należy zwrócić uwagę na istniejące praktyki nadawania wyłączności narodowym wytwórcom banknotów, dokumentów i towarzyszących im systemów IT. Takie uregulowania obecne są w systemach prawnych innych państw członkowskich UE i pozostają zgodne z przepisami UE, z uwagi na ścisłą korelację pomiędzy przedmiotem działalności a bezpieczeństwem państwa. Dotyczy to m.in. Hiszpanii, Portugalii, Austrii czy Francji, a w przypadku Niemiec zrezygnowano z tego rodzaju zamówień regulacyjnych na rzecz stałej i trwałej praktyki udzielania zamówień narodowym 
wytwórcom dokumentów (Lewandowski 2013, 15-16) ${ }^{3}$. Takie działania mitygują ryzyka bezpieczeństwa identyfikacyjnego i transakcyjnego, tj. ryzyko zakłócenia funkcjonowania państwa oraz strat finansowych wynikających z niedostatecznej ochrony związanej z produkcją dokumentów (oraz systemów IT) i środków pieniężnych. Równocześnie nadanie wyłączności w odniesieniu do sfery działalności kształtującej wiarygodność procesów transakcji i identyfikacji pozostaje racjonalne $\mathrm{z}$ ekonomicznego punktu widzenia (Lewandowski 2013,11-15). W literaturze przedmiotu wskazuje się, że państwa stosują odpowiednie rozwiązania (w tym instrumenty prawne) zapewniające utrzymanie produkcji dokumentów i banknotów w macierzystym kraju, z uwzględnieniem interesu państwowego (Girdwoyń 2007, 5). Brak takich systemowych rozwiązań w Polsce należy ocenić negatywnie, na co zwracają uwagę eksperci zajmujący się przedmiotowym zagadnieniem (np. Goc 2009, 7-12).

Schemat 3. Wiarygodność procesów transakcji i identyfikacji oraz wartości dla akcjonariusza PWPW wraz z elementami je konstytuującymi

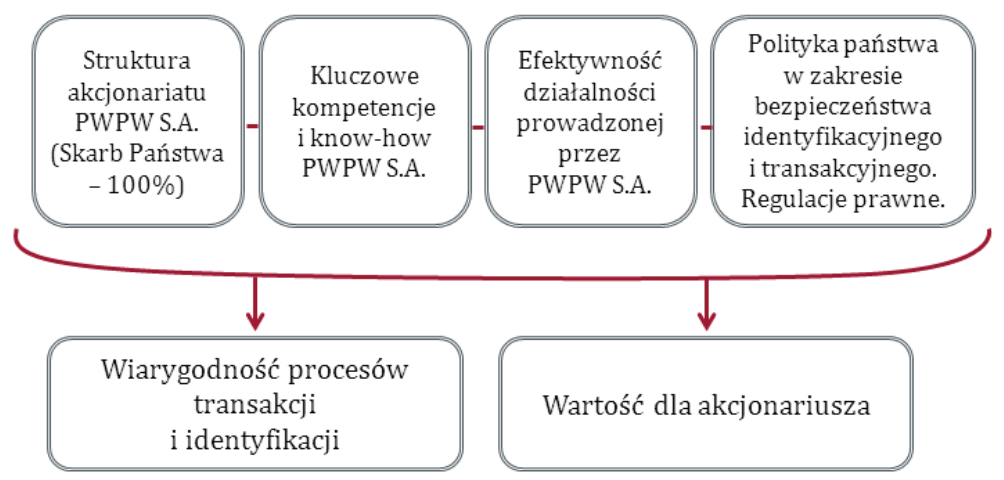

Źr ó d ło : opracowanie własne.

Brak takich uregulowań lub stabilnych i trwałych praktyk krajowych generuje ryzyko, które może osłabiać zdolność państwa do zapewnienia prawidłowych oraz bezpiecznych procesów związanych z identyfikacją oraz do realizacji towarzyszących im projektów strategicznych. Stanowi ono zatem ry-

${ }^{3}$ Warto jest przytoczyć słowa niemieckiego polityka Hansa Petera Uhla, który w 2008 r. de facto w imieniu wszystkich sił politycznych w niemieckim Bundestagu postulował, że „produkcja naszych [niemieckich] dokumentów musi pozostać w niemieckich rękach", http://www.welt.de/wirtschaft/article1767242/Staat-steigt-wieder-bei-Bundesdruckerei-ein.html. 
zyko bezpieczeństwa identyfikacyjnego i transakcyjnego, tj. ryzyko zakłócenia funkcjonowania państwa oraz strat finansowych wynikających z niedostatecznej ochrony, związanej z produkcją dokumentów i środków pieniężnych. Na ryzyko to szczególny wpływ mają następujące czynniki:

- poziom bezpieczeństwa i „szczelności” szczegółowych specyfikacji (a zatem informacji niejawnych) oraz stanów ilościowych dokumentów i środków pieniężnych;

- poziom bezpieczeństwa danych osobowych, w tym również w zakresie przesyłu danych;

- poziom bezpieczeństwa związanego z transportem środków pieniężnych, dokumentów lub półproduktów w tym zakresie;

- możliwości rozwijania własnych technologii i know-how w zakresie produkcji dokumentów oraz środków pieniężnych.

W zakresie pierwszej grupy czynników kształtujących ryzyko bezpieczeństwa identyfikacyjnego i transakcyjnego należy zauważyć, że produkcja dokumentów identyfikacyjnych oraz banknotów przez krajowy podmiot będący własnością Skarbu Państwa pozwala na stosowanie dodatkowych - poza zapisami umowy dostawy - narzędzi sprawowania kontroli nad producentem. Państwo ma prerogatywy do prowadzenia stałego nadzoru kapitałowo-właścicielskiego takiego podmiotu, co pozwala na ciągłe monitorowanie sytuacji danej spółki i odpowiednio wczesne reagowanie na ewentualne zagrożenia. Dodatkowo krajowe służby bezpieczeństwa (w przypadku PWPW jest to Agencja Bezpieczeństwa Wewnętrznego) dokonują okresowej oceny zdolności firmy do przetwarzania informacji niejawnych, które w szczególności stanowią specyfikacje techniczne dokumentów identyfikacyjnych oraz banknotów. W przypadku powierzenia produkcji podmiotowi zagranicznemu lub krajowemu podmiotowi prywatnemu wyeliminowana zostaje praktycznie możliwość wpływu na stosunki własnościowe producenta. Możliwa jest zatem sytuacja, w której dochodzi do przejęcia kapitałowego producenta dokumentów i banknotów przez inny podmiot, cieszący się mniejszym zaufaniem polskich władz. Pojawiają się ponadto ryzyka następstw ewentualnej upadłości zagranicznej lub prywatnej firmy, związane m.in. z koniecznością niezwłocznego zapewnienia zastępczego dostawcy oraz bezpieczeństwa danych przechowywanych przez tę firmę. W skrajnym przypadku taka sytuacja może prowadzić do nielegalnego wykorzystania informacji oraz materiałów oryginałowych do produkcji blankietów dokumentów i banknotów bez wiedzy kraju zamawiającego. Dokumenty takie mogą być następnie wykorzystywane zarówno przez służby specjalne ob- 
cych państw, jak i zorganizowane grupy przestępcze. Stąd istotne znaczenie ma kwestia bezpieczeństwa w zakresie każdego etapu procesu produkcyjnego oraz stanów ilościowych półproduktów i produktów generowanych na poszczególnych etapach produkcji.

Dane osobowe powinny podlegać szczególnej ochronie, ze względu na fakt, że dotyczą wszystkich obywateli, dla których produkowane są dokumenty poddawane procesowi personalizacji. Bezpieczeństwo danych osobowych narażone jest na szereg zagrożeń, takich jak udostępnienie danych osobowych osobom nieupoważnionym, przetwarzanie danych osobowych z naruszeniem przepisów, zmiana, utrata, uszkodzenie czy zniszczenie danych osobowych. Z tych względów postuluje się stosowanie centralnej personalizacji danych (im mniej ośrodków przechowujących i przetwarzających dane, tym zagrożenia mniejsze) oraz włączenie procesu personalizacji w proces produkcyjny dokumentów (Goc 2010, 6-7). Dobrym przykładem w odniesieniu do polskich dokumentów może być produkcja i sprzężona z nią personalizacja prawa jazdy, która odbywa się w PWPW.

Trzecią grupę czynników wpływających na ryzyko bezpieczeństwa identyfikacyjnego i transakcyjnego stanowią kwestie związane z transportem dokumentów (lub blankietów) czy banknotów. W szczególności w przypadku transportu międzynarodowego ryzyko kradzieży lub zagubienia partii dokumentów (blankietów) jest wyższe aniżeli w przypadku transportu krajowego czy wręcz transportu w obrębie jednego miasta. Konsekwencje zagubienia lub kradzieży dokumentów (wzorów dokumentów) mogą być bardzo poważne i pociągać za sobą nawet całkowitą zmianę wzoru dokumentu, co zdarzyło się np. w Wielkiej Brytanii w 2010 r. w odniesieniu do dowodu rejestracyjnego. Zapewnienie produkcji, w tym i personalizacji dokumentów, w jednym miejscu w znaczny sposób pozwala ograniczyć omawianą grupę ryzyka.

Czwarta grupa czynników wiąże się z odcięciem danego państwa od nowoczesnych technologii i know-how dotyczących produkcji dokumentów i banknotów. Lokowanie zamówień na dokumenty i banknoty w podmiotach zagranicznych lub niekontrolowanych przez państwo krajowych podmiotach prywatnych może prowadzić do uzależnienia technologicznego państwa od zagranicy i utraty suwerenności gospodarczej. Jak wcześniej wskazano, utrata przez państwo kontroli nad strategicznymi (kluczowymi dla gospodarki) sektorami generuje ryzyko ekonomiczne. PWPW jest podmiotem, który zapewnia innowacje i rozwój technologiczny w obszarze bezpieczeństwa transakcji i identyfikacji. Wyrazem tego są nie tylko produkowane na światowym poziomie banknoty oraz dokumenty i towarzyszące im systemy IT, ale przede wszystkim własne roz- 
wiązania technologiczne, w tym również patenty. Przykładem może być choćby papier do grawerowania laserowego LEAP, technologia kolorowej personalizacji kart poliwęglanowych PCP, karta z personalizowanym elementem niepalnym Extreme ID, personalizowany element Recto/Verso - Verso ID czy rozwiązanie TLE (Transparent Laser Engraving).

Wszystkie wymienione powyżej czynniki, kształtujące ryzyko bezpieczeństwa identyfikacyjnego i transakcyjnego, doprowadzić mogą do naruszenia funkcjonowania państwa oraz do strat finansowych poprzez wykorzystanie zdobytych w nieuprawniony sposób dokumentów (blankietów) czy środków pieniężnych lub ich falsyfikatów do działalności przestępczej, prowadzącej do zakłóceń w obrocie gospodarczym i prawnym. Przestępczość ma bowiem swoje ekonomiczne konsekwencje zarówno w stratach finansowych poszkodowanych podmiotów, jak i na poziomie PKB państw (Lewandowski 2004, 624). Realizowany przez banki centralne nadzór nad systemem płatniczym w szerokim ujęciu obejmuje także instrumenty płatnicze i infrastrukturę techniczną (Iwańczuk 2011, 51), a zatem również bezpieczny system zapewniający dostawy do banków centralnych odpowiednio zabezpieczonych (przed fałszowaniem) środków pieniężnych w ich przedemisyjnej fazie życia. Dotyczy to w szczególności banknotów, których udział w wartości gotówki w obiegu wynosi 97\% (NBP 2008, 14). Naruszenie tego elementu może doprowadzić do osłabienia stabilności finansowej, a w konsekwencji mieć wpływ na rynki finansowe. Wskazane ryzyka wpływają na podstawowy interes bezpieczeństwa państwa. Bodziony $(2012,149)$ zwraca natomiast uwagę, że zagrożenia dla systemu finansowego mają kluczowe znaczenie dla bezpieczeństwa ekonomicznego państwa. Na schemacie 4 przedstawiono układ czynników kształtujących omawiane ryzyka. Podkreślenia wymaga jednak, że wskazane elementy nie wyczerpują wszystkich czynników oddziałujących na podstawowy interes bezpieczeństwa państwa. Odnoszą się one wyłącznie do omówionych w niniejszym artykule zagadnień związanych z bezpieczeństwem identyfikacyjnym i transakcyjnym. 
Schemat 4. Bezpieczeństwo identyfikacyjne i transakcyjne na tle bezpieczeństwa państwa

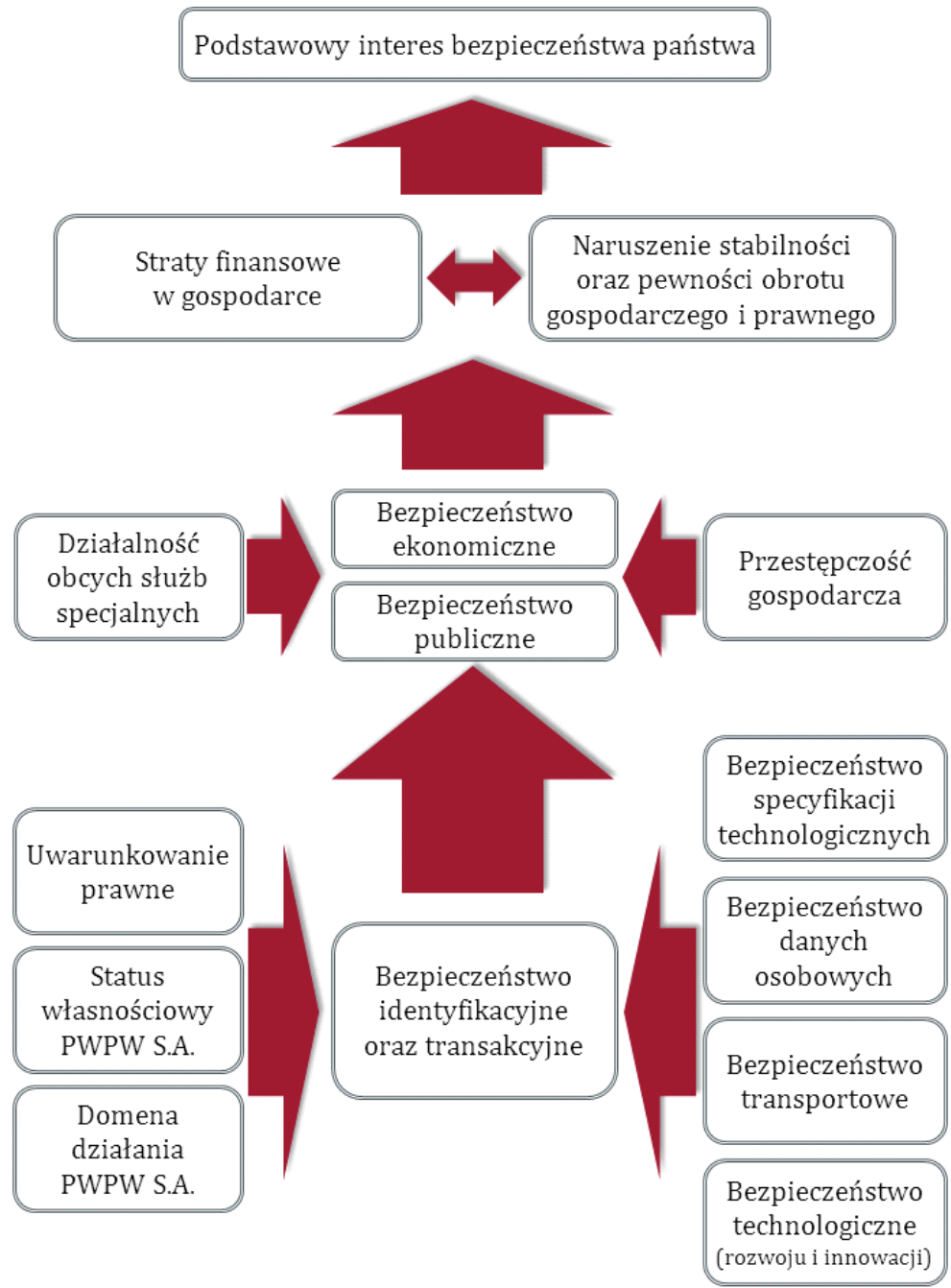

Źr ó d ło : opracowanie własne.

Warto również podkreślić, że model działania PWPW wpisuje się w postulowane w literaturze przedmiotu (Ramamurti 1987) funkcje przedsiębiorstw należących do państwa (SOE - state owned enterprise). Do najistotniejszych z tego rodzaju funkcji należy uznać: 
- realizację kluczowych interesów państwa,

- wzbogacenie narodowego potencjału technologicznego,

- kreowanie standardów płacowych,

- pełnienie funkcji agenta fiskalnego,

- kreację zatrudnienia,

- wsparcie dla mniej rozwiniętych regionów.

Realizacja kluczowych interesów państwa oraz wzbogacanie potencjału technologicznego zostały - w odniesieniu do działalności prowadzonej przez PWPW - przedstawione w niniejszym artykule. Kreowanie standardów płacowych, zwłaszcza w zakresie rzetelności, zgodności z prawem i szeroko rozumianej dobrej relacji pracownik - pracodawca także jest domeną PWPW. Funkcja agenta fiskalnego dotyczy przede wszystkim wpływów Skarbu Państwa z tytułu rzetelnie płaconych podatków oraz wpływ dywidendowych oraz unikania agresywnych strategii optymalizacji podatkowej, w tym niekorzystania z rajów podatkowych. Warto podkreślić, że tylko za lata 2007-2012 wpływy Skarbu Państwa z PWPW z tytułu dywidendy, podatku CIT, VAT i wpłaty z zysku wyniosły ponad 1,3 mld PLN. Funkcje kreacji zatrudnienia oraz wsparcia dla mniej rozwiniętych regionów są w znacznym stopniu pochodną skali działania przedsiębiorstwa. Decydentem w zakresie skali działania w kraju jest przede wszystkim administracja publiczna jako dominujący klient PWPW. Skala działania spółki jest bowiem dostosowana do potrzeb państwa, choć równocześnie zasoby firmy są wykorzystywane także do realizacji zamówień komercyjnych i zagranicznych, w szczególności dla tych państw, które nie posiadają własnych odpowiedników PWPW. W ten sposób wykorzystywane są ewentualne wolne moce produkcyjne i realizowane dodatkowe przychody, a produkty i usługi firmy kierowane niemal na wszystkie kontynenty. Charakter prowadzonej przez PWPW działalności w dużym stopniu determinuje jej lokalizację. Działalność niewymagająca centralnej lokalizacji jest jednak prowadzona w regionie atrakcyjnym pod względem kosztów pracy, a równocześnie potrzebującym inwestycji. Przykładem jest zajmująca się autoryzacją i rozliczaniem płatności kartowych na terminalach POS spółka Centrum Rozliczeń Elektronicznych Polskie ePłatności SA, której dominującym właścicielem jest PWPW i której siedziba zlokalizowana jest w Rzeszowie. Skala działalności PWPW na rynku krajowym oraz na rynkach zagranicznych, jej potencjał technologiczny, a także znaczenie dla gospodarki i bezpieczeństwa państwa wydają się sytuować ten podmiot w kategoriach narodowych czempionów. 


\section{WNIOSKI}

Polska Wytwórnia Papierów Wartościowych pełni istotną funkcję w systemie bezpieczeństwa narodowego, w tym szczególnie w obszarze bezpieczeństwa publicznego i ekonomicznego. Równocześnie jednak państwo, decydując się na udział tego rodzaju podmiotów w swoim portfelu, powinno wytworzyć odpowiednie środowisko i uwarunkowania formalno-prawne faktycznie dające impuls do dalszego wzrostu i optymalnego wykorzystania posiadanych przez nie zasobów i minimalizujące ryzyko identyfikacyjne oraz transakcyjne przez zapewnienie ciągłości i stabilności produkcji banknotów oraz dokumentów i towarzyszących im systemów IT w PWPW. Są to działania niezbędne dla zapewnienia podstawowego interesu bezpieczeństwa państwa w wymiarze ekonomicznym, prawnym i społecznym, albowiem zapewniana przez PWPW wiarygodność procesów transakcji i identyfikacji jest jednym z ważniejszych warunków przedmiotowego bezpieczeństwa. Polskie i globalne doświadczenia wskazują, że deregulacja rynków pełniących kluczowe funkcje w systemie bezpieczeństwa narodowego przynosi fatalne konsekwencje $e^{4}$. Naturalnym rozwiązaniem jest regulacja państwa i w określonych, uzasadnionych przypadkach zapewnienie narodowym wytwórcom, stanowiącym składową bezpieczeństwa narodowego, stabilności i trwałości działania, np. w formie udzielenia wyłączności na działalność w ściśle zdefiniowanym obszarze banknotów, dokumentów i związanych z nimi systemów IT. Równocześnie jednak otwiera się pole działania dla państwowego regulatora, dbającego o nienadużywanie przez (naturalnego) monopolistę swojej pozycji. Wolny rynek nie stanowi bowiem panaceum na wszystkie problemy współczesnej gospodarki, tym bardziej, jeśli dotyka to sfery bezpieczeństwa. W uzasadnionych przypadkach konieczne są od niego odstępstwa. Jak wskazuje Jakimowicz (2010, 258-259) „badania [...] dowodzą, że regulacja rynków jest jednym z najważniejszych wyzwań, jakie stoją przed współczesną ekonomią".

${ }^{4}$ Np. w konsekwencji działań liberalizujących rynek energii elektrycznej w Kalifornii i towarzyszących im przestępstw doszło do największego kryzysu energetycznego w USA, którego wymiar finansowy można mierzyć w stratach poniesionych przez stan Kalifornia w wysokości 6,3 mld USD strat, patrz: Kwinta 2011. 


\section{IITERATURA}

Bodziony K. (2012), Rola służb specjalnych w systemie instytucji odpowiedzialnych za bezpieczeństwo ekonomiczne państwa, „Przegląd Bezpieczeństwa Wewnętrznego”, 7.

Brzęk W., Goc M. (2006), Znaczenie uregulowań prawnych w aspekcie produkcji dokumentów, „Człowiek i Dokumenty”, 3.

Girdwoyń P. (2007), Dokumenty publiczne w uregulowaniach prawnych wybranych państw - Austria, „Człowiek i Dokumenty”, 6.

Goc M. (2009), O potrzebie uregulowań prawno-organizacyjnych problematyki dokumentów publicznych, „Człowiek i Dokumenty”, 13.

Goc M. (2010), Skuteczność zabezpieczeń polskich dowodów rejestracyjnych, „Człowiek i Dokumenty", 17.

Grzemski J., Krześ A. (2010), Analiza pojęcia "przestępstwa godzące w podstawy ekonomiczne państwa" w ustawie z dnia 24 maja 2002 r. o Agencji Bezpieczeństwa Wewnętrznego oraz Agencji Wywiadu, „Przegląd Bezpieczeństwa Wewnętrznego”, 2.

http://www.welt.de/wirtschaft/article1767242/Staat-steigt-wieder-bei-Bundesdruckerei-ein.html (dostęp: 05.06.2013).

Iwańczuk A. (2011), Systemy płatnicze i rynek płatności w Unii Europejskiej, CeDeWu, Warszawa.

Jakimowicz A. (2010), Źródła niestabilności struktur rynkowych, WN PWN, Warszawa.

Kitler W. (2011), Bezpieczeństwo narodowe RP. Podstawowe kategorie, uwarunkowania, system, AON, Warszawa.

Kukułka J. (2000), Zaspokajanie potrzeb i rozwiq̨zywanie konfliktów w stosunkach międzynarodowych, [w:] Stosunki międzynarodowe, geneza, struktura, dynamika, E. Haliżak, R. Kuźniar (red.), Wyd. UW, Warszawa.

Kwinta W. (2011), Kryzys energetyczny w Kaliforni, „Polska Energetyka”, 11.

Lewandowski R. (2004), Makroekonomiczne konsekwencje prania pieniędzy, [w:] Przestępczość gospodarcza z perspektywy Polski i Unii Europejskiej, A. Adamski (red.), TNOiK, Toruń.

Lewandowski R. (2013), W kierunku partnerstwa strategicznego państwa i PWPW SA, „Człowiek i Dokumenty”, 28.

Maciejewski W. (2007), Dokumenty w systemie bezpieczeństwa państwa, „Człowiek i Dokumenty", 5.

Majer P. (2012), W poszukiwaniu uniwersalnej definicji bezpieczeństwa wewnętrznego, „Przegląd Bezpieczeństwa Wewnętrznego", 7.

Misiuk A. (2008), Administracja porzq̨dku publicznego i bezpieczeństwa publicznego, Warszawa.

Narodowy Bank Polski, System płatniczy w Polsce, Warszawa 2008.

Płaczek J. (2006), Miejsce i rola bezpieczeństwa ekonomicznego w systemie bezpieczeństwa państwa, [w:] Zarzq̨dzanie bezpieczeństwem narodowym, cz. 1, T. Jemioło (kier. nauk.), AON, Warszawa. 
Popiuk-Ryksińska I. (2000), Uczestnicy stosunków międzynarodowych, ich interesy i oddziaływania, [w:] Stosunki międzynarodowe, geneza, struktura, dynamika, E. Haliżak, R. Kuźniar (red.), Wyd. UW, Warszawa.

Ramamurti R. (1987), State-owned enterprises in high technology industries: Studies in India and Brazil, Praeger, New York.

Rozporządzenia Rady Ministrów z dnia 4 października 2010 r. w sprawie wykazu przedsiębiorców o szczególnym znaczeniu gospodarczo-obronnym, Dz.U. z 2010 r. nr 198, poz. 1314 z późn. zm.

Rozporządzenie Rady Ministrów z dnia 12 lutego 2013 r. w sprawie trybu postępowania w zakresie oceny występowania podstawowego interesu bezpieczeństwa państwa, Dz.U. z 2013 r., poz. 233.

Rozporządzenie Rady Ministrów z dnia 22 października 2010 r. w sprawie określenia przedsiębiorstw państwowych oraz jednoosobowych spółek Skarbu Państwa o szczególnym znaczeniu dla gospodarki państwa, Dz.U. z 2010 r. nr 212, poz. 1387.

Rozporządzenie Rady Ministrów z dnia 30 kwietnia 2010 r. w sprawie planów ochrony infrastruktury krytycznej, Dz.U. z 2010 r. nr 83, poz. 542.

Sulowski S. (2009), W poszukiwaniu definicji bezpieczeństwa wewnętrznego, „Przegląd Bezpieczeństwa Wewnętrznego", 1.

Ustawa z dnia 12 października 2012 r. o zmianie ustawy - Prawo zamówień publicznych oraz ustawy o koncesji na roboty budowlane lub usługi, Dz.U. z 2012 r., poz. 1271.

Ustawa z dnia 16 lipca 2004 r. Prawo telekomunikacyjne, Dz.U. z 2004 r. nr 171, poz. 1800 z późn. zm.

Ustawa z dnia 16 lutego 2007 r. o zapasach ropy naftowej, produktów naftowych i gazu ziemnego oraz zasadach postepowania w sytuacjach zagrożenia bezpieczeństwa paliwowego państwa i zakłóceń na rynku naftowym, Dz.U. z 2007 r. nr 52, poz. 343 z późn. zm.

Ustawa z dnia 23 sierpnia 2001 r. o organizowaniu zadań na rzecz obronności państwa realizowanych przez przedsiębiorców, Dz.U. z 2001 r. nr 122, poz. 1320 z późn. zm.

Ustawa z dnia 26 kwietnia 2007 r. o zarządzaniu kryzysowym, Dz.U. z 2007 r. nr 89, poz. 590 z późn. zm.

Ustawa z dnia 29 stycznia 2004 r. Prawo zamówień publicznych, Dz.U. z 2004 r. nr 19, poz. 177 z późn. zm. 